西

DE GRUYter DOI: $10.2478 / \mathrm{v} 10129-011-0053-7$

Sylwia Ciaglo-Androsiuk

University of Warmia and Mazury, Department of Genetics, Faculty of Biology;

Pl. Lodzki 3; 10-967 Olsztyn; e-mail: sylwia.ciaglo@uwm.edu.pl

\title{
RELATIONSHIP BETWEEN ROOT AND YIELD RELATED MORPHOLOGICAL CHARACTERS IN PEA (PISUM SATIVUM L.)
}

\begin{abstract}
Relation between morphological traits of the root system and yield related traits is an important issue concerning efforts aiming at improving of ideotype of cultivated plants species, including pea. In this paper, to analyse the dependency between traits describing the root system morphology and yield potential, Person's and Spearman's_correlations as well as canonical correlations were used.

Root system was analyzed in 14 and 21 day-old seedlings growing in blotting-paper cylinders. Yield potential of pea was analysed in a field experiment. Results of Person's and Spearman's_correlations revealed that number of lateral roots and lateral roots density were correlated witch yield related traits. Correlation between root length and shoot length was observed only for 14 day-old seedlings. The result of canonical correlations revealed that number of lateral roots and lateral roots density had the largest effect on yield related traits. This work highlights, that in order to improve the yield of pea it might become necessary to understand genetic determination of morphological traits of the root system, especially number of lateral roots.
\end{abstract}

Key words: canonical correlations, correlations, pea, Pisum sativum, root system, yield,

\section{INTRODUCTION}

Pea (Pisum sativum L.) is valuable, high protein content crop species, used in food and food processing industry, with high significance in crop rotation system due to its inherent ability to obtain much of its nitrogen requirement from the atmosphere by forming a symbiotic relationship with Rhizobium bacteria in the soil. The versatile possibilities of usage of legumes cause a gradual increase of its cultivation area. Nowadays, legumes are cultivated on the area of 180 millions of hectares, from which 8.3 mil-

Communicated by Henryk J. Czembor 
lions are under pea cultivation. The major producing countries of pea are Canada, China, India and Russia (FAOSTAT 2011). Pisum sativum is the only species in the genus Pisum which is cultivated in Poland, and it enfold both pea used for human consumption (Pisum sativum subsp. sativum) and pea for livestock feed (Pisum sativum subsp. arvense). The biological potential of the pea, when compared to the other crops (especially grains), is not completely used which is showed by its relatively low and variable yield as well as tendency to lodging (Amelin and Parakhin, 2003; Hashemi et al., 2003; Prins and de Wit, 2006).

Previous pea selection and its ideotype creation were focused mainly on above ground part of the plant, whereas very little attention was paid to root system architecture and development, especially when compared to other crops (e.g. cereals). Moreover, the analyses of pea root system were concentrated mainly on studies of symbiotic relation with root nodule bacteria.

The root system is responsible for the anchorage of the plant in the ground, absorption and translocation of water and nutrients from the soil, synthesis and transport of growth regulators and other compounds. In some plant species root system acts also as storage organ. Moreover, in some plant species symbiosis between roots and other organisms, for example bacteria or fungi present in the rhizosphere, is observed. The appropriate structure of root system is important condition for proper performing of its functions.

Water and nutrient availability limit plant growth and yield in most agricultural ecosystems. Plants with longer and stronger root system may penetrate the soil more efficiently in search of water and inorganic nutrients. Moreover, high root biomass is of the benefit to strong shoot growth, with is necessary for high yield production (Qu et al., 2003; Jin et al., 2010).

Spectrum of variation in root system, known for example in wheat, maize or rice, suggests that approximately one-third of the plant genome control morphology, growth and functioning of the root system (Zobel, 1975; Górny, 1992). Acquired knowledge about relationship between plant productivity and root characters is necessary to improve crop plants. However, relationship which exist between root morphological traits and yield related characters were not broadly analysed in crops, especially in pea.

Studies concerning relationship between root characters and yield components under field experiment are laborious, time consuming and expensive. Therefore, it is necessary to apply new, cheaper and more efficient methods. Root architecture is generally quite complex. Important traits of the root system which affect its absorbing surface are length, area, thickness, number of root hairs and mycorhizal association (Ward et al., 1978). However simple and quite complete root system morphology is observed after only 14 days of plant growth (Lynch, 1995). Thorup-Kristensen (1998) showed that the differences in morphology of root system found 
among pea genotypes measured in the field could also be found, in spite of the much faster root development, in soilless cultures. Similar results was obtained in other studies where early observations of root development, even of seedlings in soilless culture, were well correlated with subsequent rooting depth in the field (Górny, 1978; Grzesiak et al., 1996; Mia et al., 1996; Kashiwagi et al., 2006). Girdthai et al. (2010) suggested that analysis of root characters in hydroponic culture could replace assessment in soil medium conditions.

Mentioned above findings shows, that analyses of root system morphology and development under laboratory conditions is a good alternative for complicated, not possible for serial testing and laborious field experiments. Analyses of root system in soilless cultures allow to examine high number of plants in relatively small working area in relatively short time. Therefore, in this paper the characteristic of root system was performed under laboratory conditions. The purpose of the study was to evaluate the influence of traits describing the root system morphology on yield potential of pea.

\section{MATERIAL AND METHODS}

\section{Plant material}

Four high-yielding cultivars of Pisum sativum L. were used in the present study. Two of them were white flowering cultivars (Kwestor and Piast) and two were colour flowering cultivars (Albatros and Sokolik) (Table 1).

Table 1

List of pea varieties used in this study

\begin{tabular}{|c|c|c|c|c|}
\hline Accession & $\begin{array}{l}\text { Registration } \\
\text { Year/ Ori- } \\
\text { gin }\end{array}$ & Pedigree & Short characteristic & $\begin{array}{l}\text { Breeding } \\
\text { company }\end{array}$ \\
\hline Albatros & $\begin{array}{l}\text { 1994, } \\
\text { Poland }\end{array}$ & - & $\begin{array}{l}\text { Fodder pea. Semi-dwarf cultivar, white flowers, nor- } \\
\text { mal leaf, seeds spherical and smooth, colourless testa, } \\
\text { black hilum, yellow cotyledons. }\end{array}$ & \multirow{2}{*}{$\begin{array}{l}\text { Plant } \\
\text { Breeding } \\
\text { Station in } \\
\text { Szyldak }\end{array}$} \\
\hline Sokolik & $\begin{array}{l}2001, \\
\text { Poland }\end{array}$ & $\begin{array}{l}\text { cv. Ramir × } \\
\text { cv. Grzelc }\end{array}$ & $\begin{array}{l}\text { Fodder pea. Semi-dwarf cultivar red-purple flowers, } \\
\text { leaf converted to tendrils, seed irregular, greyish olive } \\
\text { coloured testa, yellow cotyledons. }\end{array}$ & \\
\hline Kwestor & $\begin{array}{l}\text { 1991, } \\
\text { Poland }\end{array}$ & $\begin{array}{l}\text { treated by } \\
\text { gamma rays } \\
\left(\mathrm{Co}^{60}, 10 \mathrm{kR}\right) \\
\text { cv. Paloma }\end{array}$ & $\begin{array}{l}\text { Field pea. Semi-dwarf cultivar, white flowers, normal } \\
\text { leaf, seeds spherical and smooth, colourless testa } \\
\text { (rarely heavily tinted), orange-yellow cotyledons. }\end{array}$ & \multirow{2}{*}{$\begin{array}{l}\text { Plant } \\
\text { Breeding } \\
\text { in } \\
\text { Poznań }\end{array}$} \\
\hline Piast & $\begin{array}{l}1995, \\
\text { Poland }\end{array}$ & $\begin{array}{l}\text { cv. Wąsata } \times \\
\text { mutant }\end{array}$ & $\begin{array}{l}\text { Field pea. Semi-dwarf cultivar, white flowers, leaf } \\
\text { converted to tendrils, seeds spherical and smooth, } \\
\text { colourless testa, yellow cotyledons. }\end{array}$ & \\
\hline
\end{tabular}




\section{Root system analysis}

Biometrical analyses of root system involved the following traits: total length of root system, length of the primary root, number of lateral roots, lateral roots density and mean length of lateral roots. Analyses were carried on 14 and 21 day-old seedlings growing in blotting-paper cylinders. Simultaneously, analyse of shoot length was also performed. The analyses were performed in greenhouse in three replications, in three completely randomized blocks, during the autumn-winter season.

\section{Field analyses}

Field experiments were carried out at field trial on the Experimental Area of University of Warmia and Mazury in Tomaszkowo near Olsztyn (northeastern Poland). The plants were grown in field trial during the 2003 and 2004 season, in complete randomised block design with three replications. Each replication was represented by 10 plants. Plants representing each variety were grown in 1 meter length rows. Intra-row distance between plants was $10 \mathrm{~cm}$, whereas inter-row distance was kept $40 \mathrm{~cm}$. The aim of the analyses was to acquire knowledge about the yielding potential of examined cultivars. Therefore, plant supports which reduce lost in yield caused by lodging were used.

Biometrical analyses in field experiment involved following morphological characters: mean seeds weight per plant, number of seeds per plant, 1000 seeds weight, number of pods per plant, number of seed per pod, number of branches per plant and plant height.

\section{Statistical analyses}

Biometric data for all pea varieties were subjected to analyse of Person and Spearman correlation and canonical correlation. All statistical analyses were run using STATISTICA 9.0 software.

RESULTS

\section{Person and Spearman_correlations}

The relationship between root related traits and yield components was analyzed using Person's and Spearman's_correlations. Results of these analyses were presented in Table 2 . 
Pearson (P) and Spearman (S) correlation coefficients between yield related traits and root system characters 14 and 21 days old seedlings.

\begin{tabular}{|c|c|c|c|c|c|c|c|c|c|c|c|}
\hline \multirow{3}{*}{ Correlation } & \multicolumn{2}{|c|}{$\begin{array}{c}\text { Total root } \\
\text { length }\end{array}$} & \multicolumn{2}{|c|}{$\begin{array}{c}\text { Primary root } \\
\text { length }\end{array}$} & \multicolumn{2}{|c|}{$\begin{array}{l}\text { Number of lateral } \\
\text { roots per plant }\end{array}$} & \multicolumn{2}{|c|}{$\begin{array}{l}\text { Lateral root } \\
\text { density }\end{array}$} & \multicolumn{2}{|c|}{$\begin{array}{l}\text { Main length } \\
\text { lateral root }\end{array}$} & \multirow[t]{2}{*}{$\begin{array}{l}\text { Root } \\
\text { weight }\end{array}$} \\
\hline & \multicolumn{10}{|c|}{ Seedlings age [days] } & \\
\hline & 14 & 21 & 14 & 21 & 14 & 21 & 14 & 21 & 14 & 21 & 21 \\
\hline \multicolumn{12}{|c|}{ Main seed weight per plant } \\
\hline$P$ & 0.193 & 0.153 & 0.039 & 0.001 & $0.453^{* *}$ & $0.465^{* *}$ & $0.336^{*}$ & $0.373^{*}$ & 0.137 & -0.126 & 0.025 \\
\hline S & 0.178 & 0.131 & 0.084 & -0.014 & $0.468^{* *}$ & $0.501^{* *}$ & $0.357^{*}$ & $0.393^{* *}$ & 0.097 & -0.125 & 0.065 \\
\hline \multicolumn{12}{|c|}{ Number of seed per plant } \\
\hline $\mathrm{P}$ & 0.249 & 0.211 & 0.028 & 0.019 & $0.623^{* *}$ & $0.612^{* *}$ & $0.439^{* *}$ & $0.430^{* *}$ & 0.241 & -0.117 & 0.11 \\
\hline S & 0.258 & 0.231 & 0.171 & 0.084 & $0.601^{* *}$ & $0.621^{* *}$ & $0.430^{* *}$ & $0.416^{* *}$ & 0.179 & -0.109 & 0.136 \\
\hline \multicolumn{12}{|c|}{1000 seed weight } \\
\hline $\mathrm{P}$ & $-0.303^{*}$ & -0.290 & -0.030 & -0.100 & $-0.584^{* *}$ & $-0.583^{* *}$ & $-0.376^{*}$ & $-0.317^{*}$ & $-0.298^{*}$ & 0.017 & -0.187 \\
\hline S & -0.269 & -0.272 & -0.187 & -0.176 & $-0.504^{* *}$ & $-0.494^{* *}$ & $-0.364^{*}$ & -0.279 & -0.266 & -0.003 & -0.177 \\
\hline \multicolumn{12}{|c|}{ Number of pods per plant } \\
\hline $\mathrm{P}$ & 0.198 & 0.178 & -0.043 & -0.033 & $0.572^{* *}$ & $0.550^{* *}$ & $0.437^{* *}$ & $0.413^{* *}$ & 0.252 & -0.050 & 0.121 \\
\hline S & 0.222 & 0.213 & 0.091 & 0.029 & $0.554^{* *}$ & $0.521^{* *}$ & $0.386^{* *}$ & $0.363^{*}$ & 0.222 & 0.028 & 0.136 \\
\hline \multicolumn{12}{|c|}{ Main number of seed per pod } \\
\hline $\mathrm{P}$ & 0.170 & 0.124 & 0.138 & 0.109 & $0.301^{*}$ & $0.335^{*}$ & 0.151 & 0.185 & 0.009 & -0.206 & -0.022 \\
\hline S & 0.002 & -0.003 & 0.083 & 0.023 & 0.297 & $0.386^{* *}$ & 0.202 & 0.275 & -0.140 & $-0.394^{* *}$ & -0.080 \\
\hline \multicolumn{12}{|c|}{ Number of branches } \\
\hline $\mathrm{P}$ & -0.147 & -0.187 & $-0.346^{*}$ & -0.292 & $0.343^{*}$ & $0.355^{*}$ & $0.482^{* *}$ & $0.485^{* *}$ & 0.076 & $-0.313^{*}$ & 0.114 \\
\hline $\mathrm{S}$ & -0.134 & -0.195 & -0.273 & -0.290 & $0.353^{*}$ & $0.363^{*}$ & $0.481^{* *}$ & $0.470^{* *}$ & 0.094 & $-0.324^{*}$ & 0.073 \\
\hline \multicolumn{12}{|c|}{ Shoot length during harvesting } \\
\hline $\mathrm{P}$ & 0.203 & 0.246 & 0.235 & 0.239 & -0.277 & $-0.328^{*}$ & $-0.361^{*}$ & $-0.384^{* *}$ & $0.302^{*}$ & $0.545^{* *}$ & $0.313^{*}$ \\
\hline $\mathrm{S}$ & 0.224 & 0.237 & 0.113 & 0.183 & -0.183 & -0.294 & -0.217 & -0.272 & $0.383^{*}$ & $0.571^{* *}$ & 0.287 \\
\hline \multicolumn{12}{|c|}{ Shoot length of 14 day seedling } \\
\hline $\mathrm{P}$ & $0.441^{* *}$ & $0.364^{*}$ & 0.091 & 0.095 & $0.759^{* *}$ & $0.584^{* *}$ & $0.486^{* *}$ & $0.332^{*}$ & 0.300 & -0.020 & 0.289 \\
\hline $\mathrm{S}$ & $0.430^{* *}$ & $0.341^{*}$ & 0.219 & 0.066 & $0.732^{* *}$ & $0.536^{* *}$ & $0.472^{* *}$ & 0.269 & $0.312^{*}$ & 0.015 & 0.196 \\
\hline \multicolumn{12}{|c|}{ Shoot length of 21 day seedling } \\
\hline $\mathrm{P}$ & $0.339^{*}$ & 0.220 & -0.030 & 0.034 & $0.624^{* * *}$ & $0.614^{* *}$ & $0.489^{* * *}$ & $0.413^{\text {*** }}$ & 0.264 & 0.047 & $0.333^{*}$ \\
\hline S & 0.254 & 0.119 & 0.079 & -0.042 & $0.562^{* *}$ & $0.578^{* *}$ & $0.413^{* *}$ & $0.369^{*}$ & 0.162 & 0.045 & 0.271 \\
\hline
\end{tabular}

* - significant differences at $\mathrm{P}<0.05 ; * *$ - significant differences at $\mathrm{P}<0.01 ; \mathrm{P}-$ Person correlations;

$\mathrm{S}$ - Spearman correlation 
The relationship between yield related characters and root morphological traits revealed that number of lateral roots per plant was significantly and positively correlated with yield related traits: mean seeds weight per plant, number of seeds per plant, number of pods per plant and mean number of seeds per plant. Significant and positive correlation was also observed between number of lateral roots per plant and number of branches, and shoot length in 14 and 21 day-old seedlings. In case of number of lateral roots per plant and 1000 seeds weight high correlation was also observed but in opposite direction. Very similar pattern of correlations was also observed between lateral roots density and yield components. Lateral roots density was significantly and positively correlated with seeds weight per plant, number of seeds per plant, number of pods per plant, number of branches and plant height measured in seedlings. Negative correlation was observed between lateral roots density and 1000 seeds weight. Mean length of lateral roots was significantly and positively correlated with shoot length measured during harvesting. Positive correlation between mean length of lateral roots measured in 21 day-old seedlings and number of branches per plant was also observed.

Results showed also significant and positive correlation between total length of root system and shoot length but only during the first measurement (for 14 day-old seedlings). However, there was no correlation between primary root length and shoot length at all stages of plant growth. Total root length and primary root length was not also correlated with mean seeds weight per plant, number of seeds per plant, number of pods per plant and mean number of seeds per plant.

\section{Canonical correlations}

The result of canonical correlations analysis between yield related traits and root morphological traits showed nine canonical variables. The first four canonical correlations were significant (for first tree $\mathrm{p}<0.01$; for fourth $\mathrm{p}<0.05$ ). The first canonical correlations coefficient was 0.97 , the second was 0.87 , whereas the third and fourth was 0.80 and 0.75 , respectively. This implies, that the linear function of the root morphological characters and that of yield related traits have strong association as they together explained $94 \%$ of the variation for the first components. The contributions of these linear composites for the second and third canonical variates were 75 and $64 \%$, respectively (Table 3 ). 
Canonical correlations between root morphological and yield related traits

\begin{tabular}{|c|c|c|c|c|c|c|c|c|c|}
\hline \multirow{2}{*}{$\begin{array}{c}\text { Canonical } \\
\text { variates }\end{array}$} & \multirow{2}{*}{$\begin{array}{l}\text { Canonical } \\
\text { correlations }\end{array}$} & \multirow{2}{*}{$\begin{array}{c}\text { Squared } \\
\text { canonical } \\
\text { correlations }\end{array}$} & \multirow{2}{*}{$\mathrm{Chi}^{2}$ values } & \multirow{2}{*}{$\begin{array}{c}\mathrm{P} \\
\text { values }\end{array}$} & \multirow{2}{*}{$\begin{array}{c}\text { Wilks' } \\
\text { Lambda }\end{array}$} & \multicolumn{2}{|c|}{$\begin{array}{l}\text { Root morphological } \\
\text { characters }\end{array}$} & \multicolumn{2}{|c|}{$\begin{array}{l}\text { Yield related charac- } \\
\text { ters }\end{array}$} \\
\hline & & & & & & $\begin{array}{l}\text { Variance } \\
\text { extracted }\end{array}$ & $\begin{array}{l}\text { Cumulative } \\
\text { redundancy }\end{array}$ & $\begin{array}{l}\text { Variance } \\
\text { extracted }\end{array}$ & $\begin{array}{l}\text { Cumulative } \\
\text { redundancy }\end{array}$ \\
\hline $\mathrm{U}_{1} \mathrm{~V}_{1}$ & 0.970 & 0.941 & $239.064_{(126.225)}$ & 0.000 & 0.001 & 0.266 & 0.250 & 0.307 & 0.289 \\
\hline $\mathrm{U}_{2} \mathrm{~V}_{2}$ & 0.871 & 0.758 & $147.288_{(101.879)}$ & 0.000 & 0.011 & 0.120 & 0.341 & 0.033 & 0.314 \\
\hline $\mathrm{U}_{3} \mathrm{~V}_{3}$ & 0.804 & 0.647 & $101.147_{(82.528)}$ & 0.002 & 0.045 & 0.134 & 0.428 & 0.049 & 0.346 \\
\hline $\mathrm{U}_{4} \mathrm{~V}_{4}$ & 0.756 & 0.571 & $67.337_{(65.829)}$ & 0.034 & 0.126 & 0.210 & 0.548 & 0.066 & 0.384 \\
\hline $\mathrm{U}_{5} \mathrm{~V}_{5}$ & 0.650 & 0.423 & $39.803(49.801)$ & 0.265 & 0.294 & 0.009 & 0.552 & 0.154 & 0.449 \\
\hline $\mathrm{U}_{6} \mathrm{~V}_{6}$ & 0.529 & 0.280 & $21.931_{(36.415)}$ & 0.583 & 0.509 & 0.035 & 0.562 & 0.121 & 0.482 \\
\hline $\mathrm{U}_{7} \mathrm{~V}_{7}$ & 0.396 & 0.157 & $11.276_{(24.995)}$ & 0.733 & 0.707 & 0.017 & 0.564 & 0.144 & 0.505 \\
\hline $\mathrm{U}_{8} \mathrm{~V}_{8}$ & 0.325 & 0.106 & $5.728_{(15.507)}$ & 0.678 & 0.838 & 0.083 & 0.573 & 0.108 & 0.516 \\
\hline $\mathrm{U}_{9} \mathrm{~V}_{9}$ & 0.250 & 0.063 & $2.102_{(7.814)}$ & 0.551 & 0.937 & 0.063 & 0.577 & 0.018 & 0.518 \\
\hline
\end{tabular}

Nine canonical variates were generated to find the optimal combinations of variables needed to discriminate between two groups of traits. All canonical variates explained $100 \%$ of variance in set of yield related traits and $97 \%$ of variance in set of root morphological characters. The first canonical variate explained $26 \%$ of variance in set of root morphological traits and $30 \%$ in set of yield related traits. The second canonical variate explained $12 \%$ and $3 \%$ of variance, respectively (Table 3 ).

The redundancy measured for a given set of variables gives the average squared multiple correlations which explain the amount of total variability of one domain accounted for by the second domain. Rather high value of redundancy indicated on quite strong relationship between both sets of parameters. The results showed that about $57 \%$ of total variability in root related characters is accounted for by the yield related traits. $51 \%$ of variability in yield related traits is explained by root morphological features. The redundancy measured for individual canonical variates indicated that $25 \%$ of variability in the first linear function of the yield related characters were explained by root morphological characters. The first canonical variable indicated also that $29 \%$ of variability of the root morphological characters were explained by yield related traits (Table 3 ).

The intra-set structured correlations which give the magnitude and directions of the variable contribution to the variate are presented in Table 4 and Table 5 for root and yield related characters, respectively. Structural correlations are helpful to identify variables and their contribution to canonical variates. Among the yield related traits, seedling shoot length $(-0.78$ and 0.74 for 14 and 21 day-old seedlings, respectively) had the highest loadings 
on forming the first canonical variate. The first canonical variate was also under relatively large influence of number of seeds per plant (-0.63), 1000 seeds weight $(0.67)$ and number of pods per plant $(-0.60)$. Shoot length during harvesting $(-0.56)$ showed the highest contribute to the third canonical variate. Number of branches had the strongest influence on forming of the fourth canonical variate $(-0.53)$. In formation of the fifth canonical variate, mean seeds weight per plant (0.51) and mean number of seeds per pod (0.56) were the highest contributors.

Table 4

Structure correlations between root related traits and their (first five) canonical variates

\begin{tabular}{|c|c|c|c|c|c|c|c|c|c|c|c|}
\hline \multirow{2}{*}{ Traits } & \multirow{2}{*}{$\begin{array}{c}\text { Seed- } \\
\text { lings } \\
\text { age } \\
\text { [days] }\end{array}$} & \multicolumn{5}{|c|}{ Canonical lodging } & \multicolumn{5}{|c|}{ Canonical weight } \\
\hline & & $\mathrm{V}_{1}$ & $\mathrm{~V}_{2}$ & $\mathrm{~V}_{3}$ & $\mathrm{~V}_{4}$ & $\mathrm{~V}_{5}$ & $\mathrm{~V}_{1}$ & $\mathrm{~V}_{2}$ & $\mathrm{~V}_{3}$ & $\mathrm{~V}_{4}$ & $\mathrm{~V}_{5}$ \\
\hline \multirow{2}{*}{$\begin{array}{l}\text { Total root } \\
\text { length }\end{array}$} & 14 & -0.474 & -0.488 & -0.173 & -0.569 & 0.061 & -0.083 & -0.102 & -0.715 & -0.657 & 0.915 \\
\hline & 21 & -0.368 & -0.559 & -0.123 & -0.579 & 0.114 & -0.465 & -0.596 & 0.879 & 0.000 & 0.980 \\
\hline \multirow{2}{*}{$\begin{array}{l}\text { Primary root } \\
\text { length }\end{array}$} & 14 & -0.243 & -0.429 & -0.126 & -0.565 & -0.064 & -0.190 & 1.655 & 1.889 & -0.534 & -2.857 \\
\hline & 21 & -0.119 & -0.407 & -0.261 & -0.529 & 0.067 & 0.995 & -1.842 & -1.297 & 0.834 & 3.793 \\
\hline \multirow{2}{*}{$\begin{array}{l}\text { Number } \\
\text { lateral roots }\end{array}$} & 14 & -0.893 & -0.110 & 0.264 & 0.222 & -0.061 & 0.213 & -3.268 & -0.838 & 1.332 & -0.146 \\
\hline & 21 & -0.848 & 0.209 & 0.204 & 0.124 & 0.109 & -1.184 & 3.038 & 0.224 & -1.124 & -1.829 \\
\hline \multirow{2}{*}{$\begin{array}{l}\text { Lateral root } \\
\text { density }\end{array}$} & 14 & -0.600 & 0.294 & 0.324 & 0.436 & 0.027 & -0.572 & 2.309 & 1.637 & -0.762 & -1.578 \\
\hline & 21 & -0.491 & 0.445 & 0.307 & 0.414 & 0.111 & 0.994 & -2.222 & -0.462 & 0.282 & 4.366 \\
\hline \multirow{2}{*}{$\begin{array}{l}\text { Main length } \\
\text { lateral root }\end{array}$} & 14 & -0.438 & -0.144 & -0.532 & -0.234 & -0.081 & -0.273 & 0.515 & -0.310 & 0.658 & 0.057 \\
\hline & 21 & -0.038 & -0.251 & -0.507 & -0.728 & -0.165 & 0.086 & 0.146 & 0.174 & -1.474 & -0.825 \\
\hline Root weight & 21 & -0.421 & -0.012 & -0.706 & -0.206 & -0.102 & -0.180 & -0.234 & -0.844 & 0.458 & -0.144 \\
\hline
\end{tabular}

Among the root morphological traits the maximum contribution to the first canonical variate had number of lateral roots $(-0.89$ and -0.85 for 14 and 21-day old seedlings, respectively) and lateral root density (-0.60 and 0.49 for 14 and 21-day old seedlings, respectively). Root weight (-0.71) had the higher contribution to the third variate, followed by mean length of lateral roots in 14 day-old seedlings $(-0.53)$. In formation of the fourth canonical variate the most important role played total root length $(-0.57$ and -0.58 for 14 and 21 day-old seedlings, respectively), primary root length ( -0.57 and -0.52 for 14 and 21 day-old seedlings, respectively) and mean length of lateral roots in 14 day-old seedlings $(-0.73)$. 
Table 5

Structure correlations between yield related traits and their (first five) canonical variates

\begin{tabular}{|c|c|c|c|c|c|c|c|c|c|c|}
\hline \multirow{2}{*}{ Characters } & \multicolumn{5}{|c|}{ Canonical lodging } & \multicolumn{5}{|c|}{ Canonical weight } \\
\hline & $\mathrm{U}_{1}$ & $\mathrm{U}_{2}$ & $\mathrm{U}_{3}$ & $\mathrm{U}_{4}$ & $\mathrm{U}_{5}$ & $\mathrm{U}_{1}$ & $\mathrm{U}_{2}$ & $\mathrm{U}_{3}$ & $\mathrm{U}_{4}$ & $\mathrm{U}_{5}$ \\
\hline $\begin{array}{l}\text { Main seed weight } \\
\text { per plant }\end{array}$ & $-0,432$ & $-0,032$ & 0,240 & 0,047 & 0,513 & 0,904 & $-0,931$ & 2,024 & $-2,615$ & 2,966 \\
\hline $\begin{array}{l}\text { Number of seed } \\
\text { per plant }\end{array}$ & $-0,632$ & $-0,086$ & 0,119 & 0,148 & 0,469 & $-2,598$ & 2,246 & $-7,538$ & 4,331 & $-6,448$ \\
\hline 1000 seed weight & 0,667 & 0,108 & 0,075 & $-0,082$ & $-0,453$ & 0,057 & 0,165 & $-0,349$ & 1,478 & $-2,180$ \\
\hline $\begin{array}{l}\text { Number of pods } \\
\text { per plant }\end{array}$ & $-0,602$ & $-0,046$ & 0,100 & 0,064 & 0,322 & 1,206 & $-1,106$ & 5,600 & $-1,044$ & 1,912 \\
\hline $\begin{array}{l}\text { Main number of } \\
\text { seed per pod }\end{array}$ & $-0,240$ & $-0,122$ & 0,096 & 0,216 & 0,556 & 0,391 & $-0,582$ & 1,151 & $-0,355$ & 1,174 \\
\hline $\begin{array}{l}\text { Number of } \\
\text { branches }\end{array}$ & $-0,346$ & 0,168 & $-0,059$ & 0,525 & 0,460 & 0,032 & 0,552 & $-0,774$ & 0,772 & 0,403 \\
\hline $\begin{array}{l}\text { Shoot length dur- } \\
\text { ing harvesting }\end{array}$ & 0,141 & $-0,273$ & $-0,544$ & $-0,420$ & $-0,138$ & $-0,080$ & $-0,313$ & $-1,323$ & $-0,444$ & 0,029 \\
\hline $\begin{array}{l}\text { Shoot length of } 14 \\
\text { day seedling }\end{array}$ & $-0,787$ & $-0,345$ & 0,136 & 0,139 & $-0,093$ & $-0,043$ & $-1,681$ & 0,728 & 0,266 & $-0,013$ \\
\hline $\begin{array}{l}\text { Shoot length of } 21 \\
\text { day seedling }\end{array}$ & $-0,746$ & 0,202 & 0,153 & $-0,200$ & $-0,207$ & $-0,693$ & 1,318 & $-0,638$ & $-0,602$ & $-0,287$ \\
\hline
\end{tabular}

The relationships between root morphological traits and the first canonical variates clearly showed that number of lateral roots and lateral root density were the most influential characters on the set of yield components.

\section{DISCUSSION}

Statement that root system with fast growing primary root, high number of lateral roots, high number of root hairs is more efficient in absorption of water and inorganic nutrients from the soil, which may activate rapid growth of plants and their high yield, is a major simplification.

Relation between root related characters and yield related traits are more complex. Correct balance between root biomass, amount of nutrients and shoot growth is of significant mining for plant grown (Lynch, 2007). Moreover, in case of maize, root system architecture and associated capture of water was found to be more important for increase of plant biomass and yield than canopy architecture and capture of light (Hammer et al., 2009).

However, long root system is not always a desired trait for the plant because of high energetic costs associated with, for example, root respiration. Geometric modelling showed that root $\mathrm{C}$ costs could be a significant factor in the reduction of plant growth (Lynch and Beebe, 1995). Moreover, exploitation of soil resources by root system can be quite intensive and may consume more than $50 \%$ 
of daily products of photosynthesis (Fogel, 1985; Nielsen et al., 1998, 2001; Lambers et al., 2002).

On the other hand, there are many studies which results point at high dependence between length of root system and drought resistance. Deeper root systems in sorgum increased yield by $20 \%$ under drought conditions (Jordan et al., 1983). Also in rice higher yield was observed in varieties with long root system under drought stress (Ingram et al., 1994; Kanbar et al., 2009; Abd Allah et al., 2010). Nevertheless, Toorchi et al. (2006) observed the existence of a positive correlation between rice root system length and plant yield also in optimal hydration conditions. Similar results was made also by Jin et al. (2010), who founded that high-yielding soybean genotypes have greater root biomass and root length. However, in the present study correlation between root system length and yield related characters were not observed. This is in agreement with previous observations which point at lack of correlation between root and yield related traits in pea mutants and cultivars (Ciągło-Androsiuk, 2009).

Mc Phee (2005), in his comparatives analysis of pea genotypes, noticed a positive trend for root biomass production and total root length with increasing seed size. Described above relationship was not observed in this study. Sokolik with the smallest seeds, when compared to other tested cultivars, had relatively long root system with high number of quite long lateral root. The opposite relationship (the biggest seeds and short root system with small number of lateral root) was observed for Piast cultivar (data not shown).

Number of lateral roots is a heritable trait of significant meaning (Lynch, 2007). Experiments performed by Rouhani et al. (1987) indicated that number of lateral roots had a strong relationship with eggplant fruit production. Plants which were characterized by the highest number of lateral root were observed to have $54 \%$ more fruits than plants which smaller number of lateral root. Routhani et al. (1987) also noticed, that value of total plant dry weight and leaf area, were strongly affected by the number of lateral roots. They observed that plants with the highest number of lateral roots are characterized by $41 \%$ higher total plant dry weight and $21 \%$ bigger leaf area, when compared to plants with the lowest number of lateral roots.

The results of canonical correlation presented in this paper suggest that number of lateral roots and lateral roots density were the most important characters for the plant productivity. Also results of Person's and Spearman's_correlation showed that number of lateral roots and lateral roots density are significantly and positively correlated with plant yield. Similar observations were made also by Lamb et al. (2000), who observed that alfalfa genotypes with higher number of lateral roots had greater total herbage yield. Furthermore, positive correlation between lateral roots number and yield productivity were observed by McIntosh and Miller (1980) and Saindon et al. (1991) in alfalfa, Sarker et al. (2005) in lentil, and Toorchi at al. (2006) in rise. 
This study points at correlation between shoot length and root length in 14 day-old seedlings. However, analysis performed on seedlings in later stage of plant growth did not show correlation between mentioned above traits. That result may suggest that in first analysed stage of seedlings development the root and shoot have uniform growth which change later on during the plant growth. Growth of roots and shoot undoubtly undergoes the genetic regulation, however described here lack of correlation between length of the root and shoot suggests that the growth of these organs have different genetic background. Similar explanation concerning different regulation of growth of root system and shoot can be found in paper of Górny (1978), who described various length of the root system in analysed dwarf and semi-dwarf mutants of barley. Lack of correlation between growth of shoot and root system was found also among analysed cultivars and mutants of pea (McPhee, 2005; Ciągło-Androsiuk, 2009), although results of research by Święcicki (1975) showed that high pea cultivars have a clear tendency to produce a long root system

\section{CONCLUSION}

Described above interrelationships indicate that the root morphological characters such as number of lateral root and lateral root density have the greatest influence on the yielding potential of pea. The identification of Quantitative Traits Loci (QTLs) for number of lateral root could be used to improve yield production of pea. Understanding of the genetic determinants of the number of lateral roots may play an important role in creating a new pea ideotype, especially in increasing its yield.

\section{ACKNOWLEDGMENTS}

I would like to thank Professor Roman Zieliński from the Department of Genetics, University of Warmia and Mazury in Olsztyn, for the valuable suggestions. The project was supported by the European Community Grant: Marie Curie Host Fellowships for the Transfer of Knowledge, Gen Crop. Contract $\mathrm{N}^{\mathrm{o}}$ MTKD-CT-2004-509834.

\section{REFERENCES}

Abd Allah A.A., Badawy S.A., Zayed B.A., El. Gohary A.A. 2010 The Role of Root System Traits in the Drought Tolerance of Rice (Oryza sativa L.). World Academy of Science, Engineering and Technology, 68: 1378-1382.

Amelin A.V. Parakhin N.V. 2003. Scientific grounds for pea selection for fodder production. Kormoproizvodstvo, 2: 20-25. Abstract from CAB Abstract AN: 20033049804.

Ciągło-Androsiuk S. 2009. Morphological and molecular characteristic of Pisum sativum L. chosen varieties and mutants. Doctor dissertation realized in Dept. of Genetics of Faculty of Biology on University of Warmia and Mazury in Olsztyn (in Polish).

FAO/IAEA. http://www-infocris.iaea.org/MVD/ last accessed in may 2011. 
Fogel R. (1985) Roots as primary producers in below-ground ecosystems. In: A.H. Fitter, Atkinson D., Read D.J., Usher M.B. (ed.): Ecological Interactions in Soil: Plants Microbes and Animals, special publication No. 4 of the British Ecological Society. Blackwell Scientific Publications, Oxford, UK, 23-36.

Girdthai T., Jogloy S., Kesmala T., Vorasoot N., Akkasaeng C., Wongkaew S., Holbrook C.C. Jr, Patanothai A. 2010 Relationship between root characteristics of peanut in hydroponics and pot studies. Crop Science, 50: 159-167.

Górny, A. 1978. Mutations of the root system of barley (Hordeum vulgare L.) In: Klimaszewski S.M., Małuszyński M. (ed.): Mutagenesis of higher plants. University of Silesia, Katowice, 68-74. (in Polish).

Górny A.G. (1992): Genetic variation of the root system in spring barley and oat. Treatises and Monographs no. 1, IGR PAN Poznan, 1-90.

Grzesiak S., Filek W., Skrudlik G., Niziol B. 1996 Screening for drought tolerance: Evaulation of seed germination and seedling growth for drought resistance in Legume plants. Journal of Agronomy and Crop Science, 177: 245-246.

Hammer G.L., Dong Z., McLean G., Doherty A., Messina C., Schussler J., Zinselmeier C., Paszkiewicz S., Cooper M. (2009): Can changes in canopy and/or root system architecture explain historical maize yield trends in the U.S. Corn Belt? Crop Science, 49: 299-312.

Hashemi P., Banniza S., Davis A., Warkentin T., Vandenberg A. 2003 Relationships between lodging, stem anatomy, and reaction to mycosphaerella blight in field pea. In: Saskatchewan Pulse Growers, Pulse Days, Saskatoon, Canada, 64.

Ingram K.T., Bueno F.D., Namuco O.S., Yambao E.B., Beyrouty C.A. 1994 Rice root traits for drought resistance and their genetic variation. IRRI, Philippines. In: G.J.D Kirk (ed.): Rice Roots. Nutrient and Water Use, 67-77.

Jin J., Wang G., Liu X., Mi L., Li Y., Xu Y., Herbert S.J. 2010 Genetic improvement of yield shapes the temporal and spatial root morphology of soybean (Glycine max) grown in north-east China. New Zealand Journal of Crop and Horticultural Science, 38: 177-188.

Jordan W.R., Dugas W.A., Shouse P.J. 1983 Strategies for crop improvement drought-prone region. Agricultural Water Management, 7: 281-299.

Kanbar A., Toorchi M., Shashidhar H.E. 2009 Relationship between root and yield morphological characters in rainfed low land rice (Oryza sativa L.). Cereal Research Communications, 37: 261-268.

Kashiwagi J., Krishnamurthy L., Crouch J.H., Serraj R. 2006 Variability of root length density and its contributions to seed yield in chickpea (Cicer arietinum L.) under terminal drought stress. Field Crops Research, 95: 171-181.

Lamb J.F.S., Samac D.A., Barnes D., Henjum K.I 2000 Increased herbage yield in alfalfa associated with selection for fibrous and lateral roots. Crop Science, 40: 693-699.

Lambers H., Atkin O., Millenaar F.F. 2002 Respiratory patterns in roots in relation to their functioning. In: Y. Waisel, Eshel A., Kafkaki K. (ed.): Plant roots, the hidden half. 521-552.

Lynch J. 1995: Root Architecture and Plant Productivity. Plant Physiology, 109: 7-13.

Lynch J.P. 2007 Roots of the Second Green Revolution. Australian Journal of Botany, 55: 493-512.

Lynch J.P., Beebe S.E. 1995 Adaptation of bean (Phaseolus vulgaris L.) to low phosphorus availability. HortScience 30: 1165-1171.

McIntosh M.S., Miller D.A. 1980 Development of root-branching in three alfalfa cultivars. Crop Science, 20: $807-809$.

McPhee K. 2005 Variation for Seedling Root Architecture in the Core Collection of Pea Germplasm. Crop Science, 45: 1758-1763.

Mia, M.W., A. Yamauchi and Y. Kono. 1996 Root system structure of six good legume species: Inter-and intraspecific variations. Japanese Journal of Crop Sciense, 65: 131-140.

Nielsen K.L., Bouma T.J., Lynch J.P., Eissenstat D.M. 1998 Effects of phosphorus availability and vesiculararbuscular mycorrhizas on the carbon budget of common bean (Phaseolus vulgaris). New Phytologist, 139: 647-656.

Nielsen K.L., Eshel A., Lynch J.P. 2001 The effect of phosphorus availability on the carbon economy of contrasting common bean (Phaseolus vulgaris L.) genotypes. Journal of Experimental Botany, 52: 329 339 .

Prins U., de Wit J. 2006 Intercropping cereals and grain legumes: a farmers perspective. p. 292-293. In: C.Bo Andreasen, Elsgaard L., Sondergaard Sorensen L. (ed.): Organic Farming and European Rural Development Proceedings of European Joint Organic Congress, 30-31 May 2006, Odense (DK).

Qu L.Y., Ali M.Q., Takayoshi K. 2003 Root growth characteristics, biomass and nutrient dynamics of seedlings of two larch species raised under different fertilization regimes. Plant Soil, /255: 293-302.

Rouhani I., Black C.C. Jr, Vines H.M., Kormanik P.P. 1987 Effect of number of lateral roots on eggplant growth and yield. Canadian Journal of Plant Science, 67: 305-313. 
Saindon G., Michaud R., St. Pierre C.A. 1991 Breeding for root yield in alfalfa. Canadian Journal of Plant Science, 71: 727-735.

Sarker A., Erskine W., Singh M. 2005 Variation in shoot and root characteristics and their association with drought tolerance in lentil landraces. Genetic Resources and Crop Evolution, 52: 89-97.

StatSoft, Inc. 2009. STATISTICA (data analysis software system), version 9.0. www.statsoft.com.

Święcicki W.K. 1975 Studies of the root system Pisum sativum L. Hodowla Roślin 5: 15-16. (in Polish)

Thorup-Kristensen K. (1998) Root growth of green pea (Pisum sativum L.) genotypes. Crop Science, 38: 1445 $-1451$.

Toorchi M., Shashidhar H.E., Sridhara H. 2006 Influence of the root system on grain yield and related characters in rainfed lowland rice (Oryza sativa L.). Pakistan Journal of Biological Sciences, 9: 2267-2272.

Ward K.J., Klepper B., Rickman R.W., Allmaras R.R. 1978 Quantitative estimation of living wheat-root lengths in soil cores. Agronomy Journal, 70: 675-677.

Zobel R.W. 1975 The genetics of root development. In: Torrey J.G, Clarkson D.T. (ed.): The Development and Function of Roots. London: Academic Press. 261-275. 